\title{
Eco-innovation Performance in Slovakia: Assessment Based on ABC Analysis of Eco-innovation Indicators
}

\author{
Erika Loučanová,* and Martina Nosál'ová \\ The development of the global economy is accompanied by growing \\ environmental pollution, which has led to a change in attitudes and a need \\ to promote sustainability. Modern innovation policy is becoming \\ increasingly environmentally oriented. The purpose of this paper was to \\ estimate the current situation of eco-innovation's development in Slovakia. \\ Eco-innovation Index analysis results showed that, in general, Slovakia is \\ in the group of countries that are moderate innovators, with an innovation \\ performance below the European Union average. Eco-innovation \\ generally positively influences the environmental, economic, and social \\ growth of companies that gradually adopt sustainable development. \\ Therefore, it is convenient to identify the eco-innovative performance of \\ Slovakia as well as to analyze the critical issues, which may also influence \\ the desired positive development of eco-innovation in the future.
}

Keywords: Eco-Innovation Index; Eco-innovation indicators; $A B C$ analysis

Contact information: Department of Marketing, Trade and World Forestry, Technical University in Zvolen, T. G. Masaryka 24, 96053 Zvolen, Slovakia; *Corresponding author: loucanova@tuzvo.sk

\section{INTRODUCTION}

The scale of environmental problems, as well as global economic competition, has raised increasing awareness for the need to change and renew existing technological production and social behavioral patterns. Such awareness may gradually produce innovative responses leading to sustainability (Könnölä et al. 2008; Carrillo-Hermosilla et al. 2009).

According to the Oslo Manual (2005), innovation is the implementation of a new or significantly improved product or process, a new marketing method, or a new organizational method in business practice. The general definition of innovation is neutral regarding the content of change; the definition is open in all directions. In contrast, putting emphasis on innovation toward sustainable development is motivated by concern about the direction and content of the progress (Klemmer et al. 1999). Environmental innovation (eco-innovation) can be defined broadly as all measures by relevant actors (companies, politicians, unions, associations, churches, private households) that: 1.) develop new ideas, behavior, products, and processes; 2.) apply or introduce them; and 3.) contribute to a reduction of environmental burdens or to ecologically specified sustainability targets (Rennings 2000). Based on the Measuring eco-innovation (MEI) European Commission project (Kemp and Pearson 2007), eco-innovation is the production, assimilation, or exploitation of a product, production process, service, or management or business method that is novel to the organization (developing or adopting it), and that results, throughout its life cycle, in a reduction of environmental risk, pollution, and other negative impacts of resource use compared with relevant alternatives. 
Regarding the approach of eco-innovation, authors have claimed that the more innovative a company is, the more environmentally friendly it will be (Bucar et al. 2003; Dangelico and Pujari 2010; Triguero et al. 2013; Lee and Min 2015). Thus, effective management of both innovation and environmental issues suggests that companies with higher-quality innovation will take better care of the environment. Eiadat et al. (2008) and, subsequently, Zhen (2011) identified the equality and mutual benefit that proceed from the relationship between eco-innovation and a business's performance. According to Lešková (2009), eco-innovation decreases material demands by using closed material flows or by creating or using new materials. At the same time, ecological innovations are focused on decreasing energy demands or creating/using alternative sources of energy. They also decrease the total amount of emissions or existing environmental load and health risks while supporting healthy lifestyles and sustainable consumption.

Ryszko (2016) reported that companies can, through technological eco-innovation, not only improve their corporate image and achieve better customer satisfaction, but can also generate an increase in market share, profit growth, return on sales, etc. Because technological eco-innovation reduces environmental impact and improves business performance, it simultaneously contributes to environmental and economic pillars of sustainable development.

The forest-based bioeconomy and EU's Bioeconomy Strategy state that forests and related industries (wood industry etc.) have always been an important part of the bioeconomy. As a manifestation of this strategy, building houses from wood would save two tonnes of $\mathrm{CO}_{2}$ for each tonne of cement used (Intergoup 2020). The changing market environment and a non-functional innovation system in Slovakia (Štěrbová et al. 2018) forces the traditional forestry industry to adapt, and the analysed European cases indicate that business system innovations should always be considered to meet consumers' needs. The business models introduce new organizational channels for reaching customers, satisfying new customer needs, targeting unique customers, reducing transaction costs, and improving customer relationships (Štěrbová et al. 2016; Šoltés and Štofková 2016; Kajanus et al. 2019; Loučanová and Olšiaková 2020). For the purpose of innovations development, Rametsteiner and Weiss (2006) propose a more complex system view of innovation "as a complex non-linear process involving a range of players and different interactions", with the focus on the social elements of the system. New wood-based plastics and textile products with lower environmental footprint are also emerging within the bioeconomy. Even though there are limitations on how much biomass can be produced, there is still unlocked potential and further innovations to be discovered (Intergoup 2020; Kalamárová et al. 2014).

Furthermore, Picazo-Tadeo et al. (2014) and Färe et al. (1994) stated that a change in environmental performance is part of proportionate eco-efficiency change and also environmental technical change. Eco-innovation can serve as a tool by which companies attempt to transform environmental constraints into opportunities to reduce costs, to obtain a better reputation, and to take advantage of new markets. One of the most important consumer interests is the promotion of environmental product innovation and performance. (Carrillo-Hermosilla and Unruh 2006; Laperche and Picard 2013; Loucanova et al. 2015).

This paper is largely based on the approach of the European Commission (European Commission 2011). The Eco-Innovation Index, a composite index indicator, allows measuring the eco-innovation performance of different EU member states. The ranking of EU member states is dependent on their deviation from the EU average. In 2017, the highest rated EU country was Sweden as the leader in this field, followed by Finland, 
Germany, Luxembourg, Denmark, Slovenia, Austria, Italy, Spain, Portugal, and the United Kingdom, which all obtained higher ratings than the EU average.

The Eco-Innovation Index of Slovakia in 2017, compared with other EU countries was below the EU average. Slovakia was among the ten member states with the lowest ranking in this field. The obtained score of 74 ranked Slovakia in $21^{\text {st }}$ place of $28 \mathrm{EU}$ countries. Slovakia was in the group of moderate innovators countries with an innovation performance below the EU average.

In the case of the Eco-Innovation Index, a high overall ranking does not necessarily mean that a country has performed well in all eco-innovation areas covered by this index. The results of the index can only provide an indication of the overall country performance of eco-innovation. Rizos et al. (2015) emphasized that drawing conclusions about specific eco-innovation aspects and country trends requires a careful analysis of the sub-indicators covering these fields, for that the aim this article is analyze the current situation of ecoinnovation's development in Slovakia.

\section{EXPERIMENTAL}

This paper evaluated Slovakia's eco-innovation situation, which is defined according to the Eco-Innovation Index and its five thematic areas. Using ABC analysis, the aim is to identify the most important areas influencing eco-innovation development in Slovakia. According to the European Commission, the Eco-Innovation Index (European Commission 2011) shows how well individual member states perform in different dimensions of eco-innovation compared with the European Union (EU) average, and presents their strengths and weaknesses. The intention of the Index is to acquire various aspects of eco-innovation by applying 16 different indicators that are grouped into five thematic areas: eco-innovation inputs, eco-innovation activities, eco-innovation outputs, resource efficiency, and socio-economic outcomes (Table 1).

According to the European Commission (2011), every area is measured according to a score. The Eco-Innovation Index is counted individually for each country, where specific figures of a single indicator are weighted with the share of the population. The "distance-to-reference" method is used to normalize different indicators. The EU average is defined as the reference, and a set is defined as a value of 100. Countries whose figures are higher than the EU average obtain a higher score than 100, and countries whose figures are lower receive a score lower than 100 . The specific value is dependent on the deviation from the EU average.

The value to index consists of 16 indicators from 8 different data sources. Thus the EU average of a sub-indicator displays the weighted mean of all country specific data of the EU Member States. The value of the sub-index in each of the five areas is calculated by the unweighted mean of the values to underlying indicators. Consequently, each indicator has the same weighting in the five areas. The overall index value of each EU Member State is calculated by the unweighted mean of the 16 indicators in order to avoid a bias between the thematic areas of the index (European Commission 2011).

First, to evaluate the current situation in the area of eco-innovation in Slovakia, the authors of the present study analyzed the Eco-Innovation Index data for the year 2017 and the causalities in its developments in the years 2010 to 2017. 
Table 1. Thematic Areas of Innovation Index

\begin{tabular}{|c|c|c|c|c|}
\hline $\begin{array}{l}\text { Eco-innovation } \\
\text { Inputs }\end{array}$ & $\begin{array}{l}\text { Eco-innovation } \\
\text { Activities }\end{array}$ & $\begin{array}{l}\text { Eco-innovation } \\
\text { Outputs }\end{array}$ & $\begin{array}{l}\text { Resource } \\
\text { Efficiency } \\
\text { Outcomes }\end{array}$ & $\begin{array}{c}\text { Socio- } \\
\text { economic } \\
\text { Outcomes }\end{array}$ \\
\hline $\begin{array}{l}\text { Governments' } \\
\text { environmental } \\
\text { and energy } \\
\text { research and } \\
\text { development } \\
\text { appropriations } \\
\text { and outlays }\end{array}$ & $\begin{array}{c}\text { Enterprises that } \\
\text { introduced an } \\
\text { innovation with } \\
\text { environmental } \\
\text { benefits obtained } \\
\text { within the } \\
\text { enterprise }\end{array}$ & $\begin{array}{l}\text { Eco-innovation- } \\
\text { related patents }\end{array}$ & $\begin{array}{l}\text { Material } \\
\text { productivity }\end{array}$ & $\begin{array}{c}\text { Exports of } \\
\text { products from } \\
\text { eco-industries }\end{array}$ \\
\hline \multirow[t]{2}{*}{$\begin{array}{l}\text { Total research } \\
\text { and development } \\
\text { personnel and } \\
\text { researchers }\end{array}$} & \multirow{2}{*}{$\begin{array}{l}\text { Enterprises that } \\
\text { introduced an } \\
\text { innovation with } \\
\text { environmental } \\
\text { benefits obtained } \\
\text { by the end user }\end{array}$} & \multirow[t]{2}{*}{$\begin{array}{l}\text { Eco-innovation } \\
\text { related academic } \\
\text { publications }\end{array}$} & $\begin{array}{c}\text { Water } \\
\text { productivity }\end{array}$ & \multirow[t]{2}{*}{$\begin{array}{l}\text { Employment in } \\
\text { eco-industries }\end{array}$} \\
\hline & & & $\begin{array}{c}\text { Greenhouse } \\
\text { gas emissions } \\
\text { intensity }\end{array}$ & \\
\hline $\begin{array}{c}\text { Total value of } \\
\text { green early stage } \\
\text { investments }\end{array}$ & $\begin{array}{c}\text { ISO } 14001 \\
\text { (2015)-registered } \\
\text { organizations }\end{array}$ & $\begin{array}{l}\text { Eco-innovation } \\
\text { related media } \\
\text { coverage }\end{array}$ & $\begin{array}{l}\text { Energy } \\
\text { productivity }\end{array}$ & $\begin{array}{c}\text { Turnover in } \\
\text { eco-industries }\end{array}$ \\
\hline
\end{tabular}

Source: Authors according to Eco-Innovation Index, European Commission (European Commission 2011)

As the second step, the ABC analysis of the individual areas' influence on the value of Eco-Innovation Index in Slovakia was calculated based on the European Commission's eco-innovation data (European Commission 2011). The ABC analysis can use different criteria to group "items," resulting in various groupings. The use of ABC analysis to rank items depends on the goals a company's management needs to accomplish (Coyle 2009). According to Li et al. (2018), ABC analysis is a popular and effective method used to classify items into specific categories that can be managed and controlled separately. The three predefined and ordered categories are:

1. Category A, which contains the very important items (approximately 70 to $80 \%$ share of the total value of the parameter, and approximately 10 to $15 \%$ share of the total number of elements);

2. Category B, which includes the moderately important items (approximately 15 to $20 \%$ share of the total value of the parameter, and approximately 15 to $20 \%$ share of the total number of elements);

3. Category $\mathrm{C}$, which contains the relatively unimportant items (approximately 5 to $10 \%$ of the total value of the parameter, and about 60 to $80 \%$ of the total number of elements).

This classification is based on the Pareto principle and the analysis of a range of items that have different levels of importance, and thus should be handled or controlled differently. Graphic presentation of the ABC analysis results is completed using the Lorenz curve, an indicator that reflects the concentration of the studied phenomenon. The curve plots the cumulative expression of the individual variables ("Lorenz Curve").

In inventory management, $\mathrm{ABC}$ analysis is the most widely used technique $(\mathrm{Ng}$ 2007; Douissa and Jabeur 2016). According to Chen et al. (2008), a recent trend is to develop various procedures to conduct $\mathrm{ABC}$ analysis in terms of multiple criteria. In the present study, $\mathrm{ABC}$ analysis provided information on how the individual thematic areas contributed to the absolute value of Slovakia's Eco-Innovation Index. It provided a 
mechanism for identifying areas that could have a remarkable impact on the overall ecoinnovation situation in Slovakia. The identified areas are important for deciding whether to support or eliminate these thematic areas within the strategy in Slovakia.

All thematic areas of the Eco-Innovation Index were chosen as the evaluation object, and they were listed in descending order according to their contribution to Slovakia's Eco-Innovation Index. Subsequently, percentage shares of individual thematic areas were calculated, and, according to the calculation of the accumulated value (\%), the results were presented graphically using the Lorenz curve.

\section{RESULTS AND DISCUSSION}

The Eco-Innovation Index also aims to assess how eco-innovation is unfolding in several relevant areas such as research and development (R\&D) investments, the performance of firms, and socio-economic and environmental outcomes. The Index includes 16 different indicators that are classified into five thematic categories: ecoinnovation inputs, eco-innovation activities, eco-innovation outputs, resource efficiency outcomes, and socio-economic outcomes.

For more in-depth analysis, the present study identified the value of all 16 individual indicators of the Eco-Innovation Index thematic areas of Slovakia, per the ecoinnovation data of European Commission. Their percentages were calculated, as well as the cumulative values that classify these indicators into Group A, B, or C according to their importance for eco-innovation in Slovakia (Table 2).

Table 2. Data for ABC Analysis Eco-Innovation Index Indicators of Slovakia in 2017 According to the Eco-Innovation Database

\begin{tabular}{|c|c|c|c|}
\hline Indicators of Eco-Innovation Index of Slovakia & Value & $\%$ of Total & Cumulative \% \\
\hline Water Productivity & 252 & 18.42 & 18.42 \\
\hline ISO 14001 (2015)-registered Organizations & 252 & 18.42 & 36.84 \\
\hline Turnover in Eco-industries & 227 & 16.59 & 53.43 \\
\hline Employment in Eco-industries & 117 & 8.55 & 61.99 \\
\hline GHG Emissions Intensity & 75 & 5.48 & 67.47 \\
\hline Material Productivity & 70 & 5.12 & 72.59 \\
\hline Energy Productivity & 62 & 4.53 & 77.12 \\
\hline Exports of Products from Eco-industries & 52 & 3.80 & 80.92 \\
\hline Eco-innovation-related Academic Publications & 48 & 3.51 & 84.43 \\
\hline Eco-innovation-related Media Coverage & 45 & 3.29 & 87.72 \\
\hline $\begin{array}{c}\text { Enterprises that Introduced an Innovation with } \\
\text { Environmental Benefits Obtained within the Enterprise }\end{array}$ & 43 & 3.14 & 90.86 \\
\hline $\begin{array}{c}\text { Enterprises that Introduced an Innovation with } \\
\text { Environmental Benefits Obtained by the End User }\end{array}$ & 43 & 3.14 & 94.00 \\
\hline Total R\&D Personnel and Researchers & 38 & 2.78 & 96.78 \\
\hline Governmental Environmental and Energy R\&D & 32 & 2.34 & 99.12 \\
\hline Appropriations and Outlays & 11 & 0.80 & 99.93 \\
\hline Eco-innovation-related Patents & 1 & 0.07 & 100.00 \\
\hline Total Value of Green Early Stage Investments & & & \\
\hline
\end{tabular}


The impact of the Eco-Innovation Index individual indicators in Slovakia is illustrated in Fig. 1. Items in Category A are the most important and contribute quite heavily to Slovakia's eco-innovation index. They include water productivity, ISO 14001 (2015)-registered organizations, and turnover in eco-industries. Category B items represent moderately important items with much potential to improve, and include employment in eco-industries, the level of GHG emissions, and material productivity. The remaining items fall within Group $\mathrm{C}$, which has the highest number of indicators but the lowest share of the total Eco-Innovation Index effect.

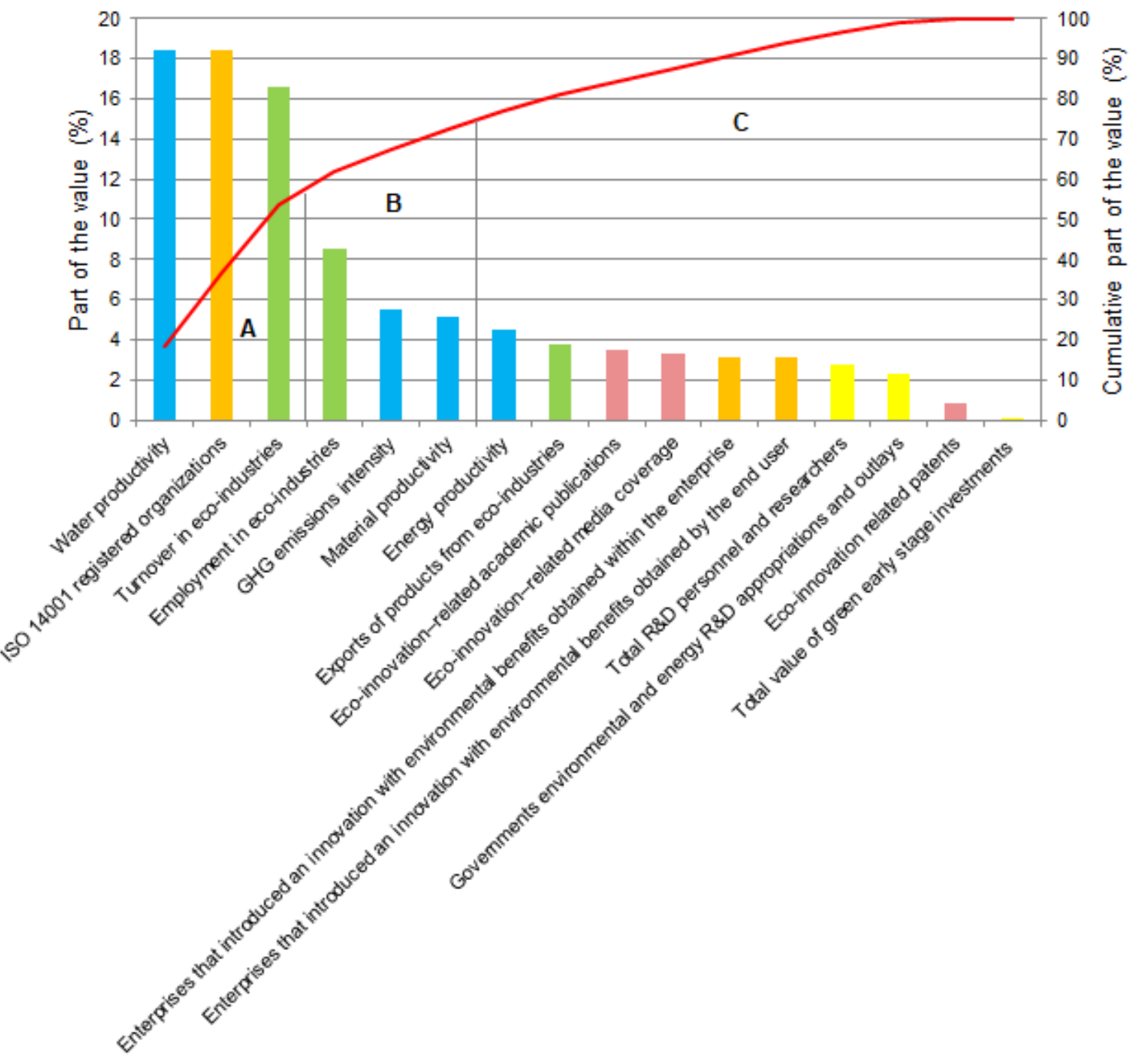

Indicators of Eco-Innovation Index

Fig. 1. ABC analysis of Eco-Innovation Index indicators of Slovakia in 2017 according to the EcoInnovation Database

The Eco-Innovation Index is positively influenced mainly by the activities carried out in the mentioned areas (socio-economic outcomes, eco-innovation activities, and resource efficiency outcomes), namely activities of water productivity, ISO 14001 (2015)registered organizations, turnover in eco-industries, the level of Greenhouse gas (GHG) emissions, employment in eco-industries, and material productivity according to $\mathrm{ABC}$ 
analysis (Categories $\mathrm{A}$ and $\mathrm{B}$ ). The other conducted activities did not influence to a significant extent the positive development of eco-innovation in Slovakia as greatly (Category C). The value of green early stage investment had the least impact on the ecoinnovation index, because forestry is often considered as a "Low-tech" declining industry (Rametsteiner and Weiss 2006), which invests relatively little into research, development and innovation (Loučanová et al. 2017).

Eco-innovation in Slovakia has an increasing tendency (Fig. 2), when observing development in the years 2010 to 2017. It is worth noticing that 2013 was heavily influenced by indicators in the area of socio-economic outcomes, and the value reached a low of 42. The current situation is different and socio-economic outcome indicators report the highest values, affecting the overall Eco-Innovation Index.

The Eco-Innovation Index in Slovakia has generally increased over time, except for slight decreases in 2013 and 2017. The monitored areas of resource efficiency outcomes, socio-economic outcomes, and eco-innovation activities all demonstrated an upward trend; however, the areas of eco-innovation inputs and outputs demonstrated slightly descending trend in 2017. That decrease, according to ABC analysis, was noticeably caused by negative development, mainly in the total value of green early stage investments, ecoinnovation-related patents, governmental environmental and energy R\&D appropriations and outlays, and total R\&D personnel and researchers. The area of eco-innovation outputs stagnated.

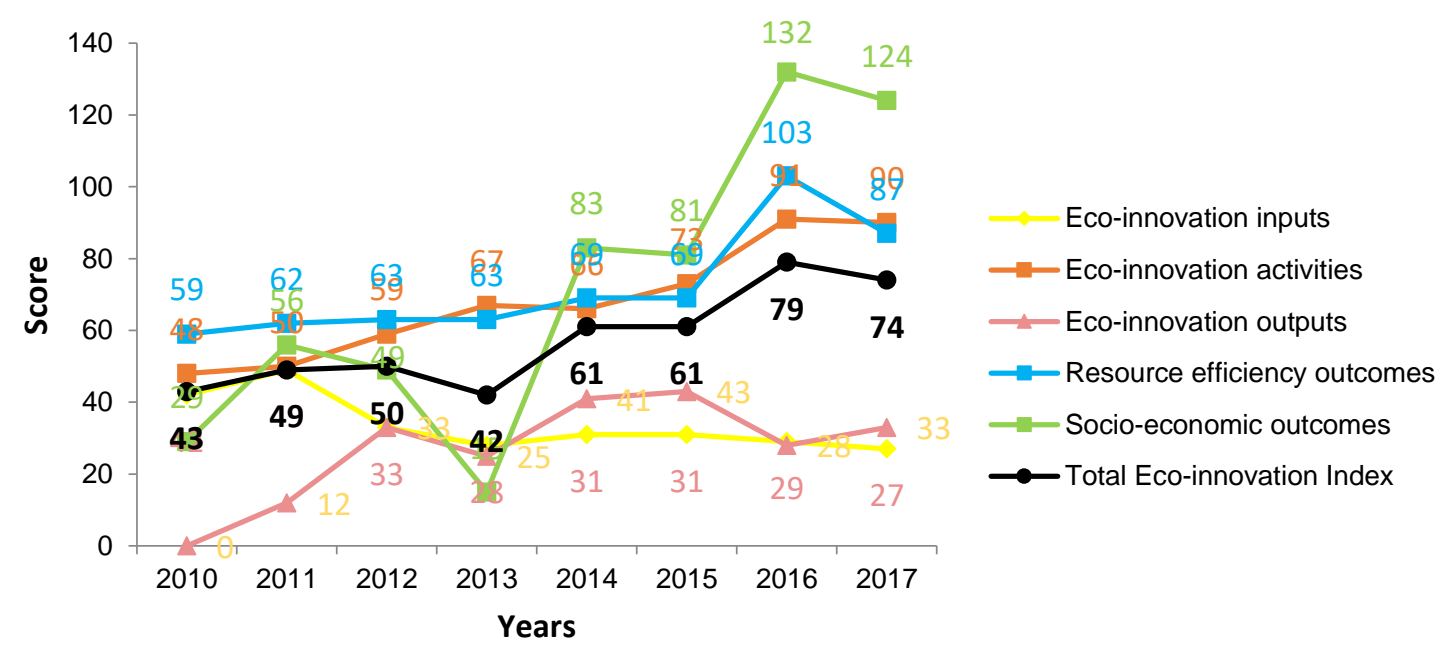

Fig. 2. Development of Eco-Innovation Index thematic areas in Slovakia in 2017, according to the Eco-Innovation Database (European Commission 2011)

In order to reverse negative development of the eco-innovation index in the last year and for its further growth, it is convenient to support eco-industry product exports, material and energy productivity, research and development in the area of the environment, energy research within the open system of innovations, and also research in other areas connected to Slovakia's environmental policy.

On the basis of the above findings, promoting eco-innovation in Slovakia has a growing tendency. Therefore, eco-innovation in Slovakia should continue to be implemented. Continued support for eco-innovation in Slovakia would encourage a positive growth rate of the Eco-innovation Index as it approaches the EU average. 
In Slovakia, eco-innovation is supported in particular by the National Strategy for Sustainable Development approaches (Úrad Vlády SR 2001). The strategy is directly linked to the major priorities of the EU, the United Nations, and the Organization for Economic Cooperation and Development, which support eco-innovation and sustainable development. This strategy deals with economic growth focused on the long-term needs of society and the respect of environmental approaches. It takes into account the criteria for maintaining and supporting biodiversity, vitality, and the resilience of ecosystems; optimizing the spatial arrangement and functional use of the landscape and ensuring its territorial system of ecological stability; maintaining and supporting life-assurance systems; maintaining a high quality of the environment; and minimizing the use of limited resources.

However, there is still space for improvement, as the overall Eco-Innovation Index of Slovakia is below average within the standards of the EU. To improve the situation, it is convenient to focus mainly on supporting the exports of products from eco-industries, environmental research and development, energy research within the open system of innovations, and research in other areas connected to Slovakia's environmental policy. These areas have lower values as monitored indicators within the Eco-Innovation Index. According to a study by Jeck (2012), environmental regulation and pollution taxes are the most important factors in introducing eco-innovation to Slovak companies. An important factor related to eco-innovation is also the effort to reduce material and energy costs. Compared with companies in other EU countries, Slovak companies are less affected by customer demand, by the financial incentives offered by the public sector, and by the adoption of voluntary codes and agreements within the industry.

The most remarkable barriers to eco-innovation in Slovak companies are financial factors and factors related to uncertain development (market or investment). Attempting to reduce energy and material demand, Slovak companies recycle, outsource production activities, and purchase finished technology. Preferring to purchase ready-made technology rather than developing it themselves is characteristic of Slovak companies' ecoinnovation behavior. As mentioned by Hrabynskyi et al. (2017), all EU members generally face the same barriers to eco-innovation, and policy-makers are obliged to address existing restrictions to correct and implement effective methods and instruments of eco-innovation policy. Additionally, according to the Eco-Innovation Observatory (EIO) Country Profile (European Commission 2011), the regulatory and policy framework for innovation is highly fragmented and insufficient in its promotion of environmentally friendly behavior in Slovakia. The lack of market demand for innovation and the low level of public awareness on this topic are also barriers.

The contribution of this paper's findings points not merely to the current status of Slovakia in terms of eco-innovation, but also to a way to identify weaknesses and opportunities for eco-innovation improvements leading to environmental and economic pillars of sustainable development. That is the very essence of eco-innovation, as, according to Mavi and Standing (2017), companies eco-innovate to promote eco-efficiency and sustainability and for environmental friendliness. Eco-innovation can serve as a tool by which companies attempt to transform environmental constraints into opportunities that can reduce costs, earn them a better reputation, and give them the advantage of new markets. One of the most important interests to a country's policies is to promote the performance and implementation of environmental product innovations (Färe et al. 1994; Carrillo-Hermosilla et al. 2009; Parobek et al. 2014; Picazo-Tadeo et al. 2014). 


\section{CONCLUSIONS}

1. Slovakia has a low level of eco-innovative efficiency.

2. Slovakia has a score below the average of the European Union's 28 countries and needs a more effective supporting program.

3. Eco-Innovation in Slovakia is positively influenced mainly by the activities of water productivity, ISO 14001 (2015); registered organizations; and turnover in ecoindustries (approximately 53.4\% share of the total value of the Eco-Innovation Index)

4. Slovakia's negative development in the last few years has been mostly in the area of eco-innovation inputs and outputs.

\section{ACKNOWLEDGMENTS}

The authors are grateful for the support of the Scientific Grant Agency of the Ministry of Education, Science, Research and Sport of the Slovak Republic, and of the Slovak Academy of Sciences, Grant No. 11/0674/19, "Proposal of a model for the ecoinnovation integration into the innovation process of companies in Slovakia in order to increase their performance."

\section{REFERENCES CITED}

Carrillo-Hermosilla, J., and Unruh, G. C. (2006). "Technology stability and change: An integrated evolutionary approach," Journal of Economic Issues 40(3), 707-742. DOI: 10.1080/00213624.2006.11506942

Carrillo-Hermosilla, J., Del González, P. R., and Könnölä, T. (2009). "What is ecoinnovation?," in: Eco-Innovation, Palgrave Macmillian, London, England, pp. 6-27. DOI: 10.1057/9780230244856_2

Chen, Y., Li, K. W., and Liu, S. F. (2008). "A comparative study on multicriteria ABC analysis in inventory management," in: Proceedings of the 2008 IEEE International Conference on Systems, Man and Cybernetics, Singapore, Singapore, pp. 3280-3285. DOI: 10.1109/ICSMC.2008.4811802

Coyle, J. J. (2009). Supply Chain Management: A Logistics Perspective, South-Western Cengage Learning, Boston, MA, USA.

Dangelico, R. M., and Pujari, D. (2010). "Mainstreaming green product innovation: Why and how companies integrate environmental sustainability," Journal of Business Ethics 95(3), 471-486. DOI: 10.1007/S10551-010-0434-0

Douissa, M. R., and Jabeur, K. (2016). "A new model for multi-criteria ABC inventory classification: PROAFTN method," Procedia Computer Science 96, 550-559. DOI: 10.1016/j.procs.2016.08.233

Eiadat, Y., Kelly, A., Roche, F., and Eyadat, H. (2008). "Green and competitive? An empirical test of the mediating role of environmental innovation strategy," Journal of World Business 43(2), 131-145. DOI: 10.1016/j.jwb.2007.11.012

European Commission (2011). Innovation for a Sustainable Future - The Eco-Innovation Action Plan, The Commission to the European Parliament, The Council, The 
European Economic and Social Committee and the Committee of the Regions (Procedure No. 201206), Brussels, Belgium.

Färe, R., Grosskopf, S., Norris, M., and Zhang, Z. (1994). "Productivity growth, technical progress, and efficiency change in industrialized countries," The American Economic Review 84(1), 66-83.

Hrabynskyi, I., Horin, N., and Ukrayinets, L. (2017). "Barriers and drivers to ecoinnovation: Comparative analysis of Germany, Poland and Ukraine," EkonomickoManazerske Spektrum 1, 13-24.

Intergroup (2020)._Forest-based Bioeconomy and EU's Bioeconomy Strategy, Brussels, Belgium.

ISO 14001 (2015). "Environmental management systems," International Organization for Standardization, Geneva, Switzerland.

Jeck, T. (2012). “Ekologické inovácie: Teoretické a hospodársko-politické súvislosti [Eco-innovation: Theoretical and economic-political context]," Institute of Economic Research 42, 3-28.

Kalamárová, M., Parobek, J., Loučanová, E., and Trebuňa, P. (2014). “Competitiveness evaluation of the Slovak forest industry”, in: Proc. 7th Int. Scientific Conf. of Int. Assoc. for Economics and Management in Wood Processing and Furniture Manufacturing (WoodEMA), Zvolen, Slovakia, pp. 58-62.

Kemp, R., and Pearson, P. (2007). Final Report MEI Project About Measuring EcoInnovation (Call FPG-2005-SSP-5A), European Commission, Brussels, Belgium.

Klemmer, P., Lehr, U., Löbbe, K. (1999). Environmental Innovation: Incentives and Barriers, Analytica, Berlin, Germany.

Könnölä, T., Carrillo-Hermosilla, J., and Del Río Gonzalez, P. (2008). "Dashboard of eco-innovation," in: Proceedings of the 2008 DIME Internatoinal Conference "Innovation, Sustainability, and Policy," Bordeaux, France, pp. 1-26.

Kajanus, M., Leban, V., Glavonjić, P., Krč, J., Nedeljković, J., Nonić, D., Nybakk, E., Posavec, S., Riedl, M., Teder, M., Wilhelmsson, E., Zālīte, Z., and Eskelinen, T. (2019). "What can we learn from business models in the European forest sector: Exploring the key elements of new business model designs," Forest Policy and Economics 99, 145-156. DOI: 10.1016/j.forpol.2018.04.005

Laperche, B., and Picard, F. (2013). "Environmental constraints, product-service systems development and impacts on innovation management: Learning from manufacturing firms in the French context," Journal of Cleaner Production 53, 118-128. DOI: 10.1016/j.jclepro.2013.03.047

Lee, K. H., and Min, B. (2015). "Green R\&D for eco-innovation and its impact on carbon emissions and firm performance," Journal of Cleaner Production 108(A), 534-542. DOI: $10.1016 /$ j.jclepro.2015.05.114

Lešková, I. A. (2009). "Politika eko-inovácií a jej prejavy v automobilovom priemysle [Eco-innovation policy in automotive industry]," Transfer Inovácii 13, 37-40.

Li, J., Wang, J., Xu, N., Hu, Y., and Cui, C. (2018). "Importance degree research of safety risk management processes of urban rail transit based on text mining method," Information 9(2), Article number 26. DOI: 10.3390/info9020026

Loucanova, E., Parobek, J., Kalamarova, M., Palus, H., and Lenoch, J. (2015). "Ecoinnovation performance of Slovakia," Procedia Economics and Finance 26, 920-924. DOI: $10.1016 / \mathrm{s} 2212-5671(15) 00906-5$

Loučanová, E., Paluš, H., and Dzian, M. (2017). “A course of innovations in wood processing industry within the forestry-wood chain in Slovakia: AQ methodology 
study to identify future orientation in the sector," Forests 8(6), 210.

Loučanová, E., and Olšiaková, M. (2020). "Identification of customers'drivers for the wood building as an ecological innovation in building construction in Slovakia," Acta Facultatis Xylologiae Zvolen 62(1), 177-188.

Mavi, R. K., and Standing, C. (2017). "Eco-innovation analysis with DEA: An application to OECD countries," IADIS International Journal on Computer Science and Information Systems 12(2), 133-147.

Ng, W. L. (2007). "A simple classifier for multiple criteria ABC analysis," European Journal of Operational Research 177(1), 344-353. DOI: 10.1016/j.ejor.2005.11.018

"Lorenz Curve," OECD Glossary of Statistical Terms, (https://stats.oecd.org/glossary/detail.asp?ID=4843), Accessed 5 April 2020.

Parobek, J., Paluš, H., Kaputa, V., and Šupín, M. (2014). "Analysis of wood flows in Slovakia," BioResources 9(4), 6453-6463. DOI: 10.15376/biores.9.4.6453-6462

Picazo-Tadeo, A. J., Castillo-Giménez, J., and Beltrán-Esteve, M. (2014). “An intertemporal approach to measuring environmental performance with directional distance functions: Greenhouse gas emissions in the European Union," Ecological Economics 100, 173-182. DOI: 10.1016/j.ecolecon.2014.02.004

Rametsteiner, E., and Weiss, G. (2006). "Innovation and innovation policy in forestry: Linking innovation process with systems models," Forest Policy and Economics 8(7), 691-703. DOI: 10.1016/j.forpol.2005.06.009

Rennings, K. (2000). "Redefining innovation-Eco-innovation research and the contribution from ecological economics," Ecological Economics 32(2), 319-332. DOI: 10.1016/S0921-8009(99)00112-3

Rizos, V., Behrens, A., and Taranic, I. (2015). Measuring Progress in Eco-innovation, (Working Document No. 409), Center for European Policy Studies, Brussels, Belgium.

Ryszko, A. (2016). "Proactive environmental strategy, technological eco-innovation and firm performance-Case of Poland," Sustainability 8(2), Article number 156. DOI: $10.3390 / \mathrm{su} 8020156$

Šoltés, V., and Štofková, K. R. (2016). "The impact of business environment on regional disparities," CBU international conference proceedings 4, 187-191.

Štěrbová, M., Šálka, J., and Sarvašová, Z. (2018). "How does the innovation system in the Slovak forestry service sector work?," Allg. Forst u. Jagdzeitung 189(1-2), 16-29.

Štěrbová, M., Loučanová, E., Paluš, H., Ivan, L., and Šálka, J. (2016). “Innovation strategy in Slovak forest contractor firms-A SWOT analysis," Forests 7(6), 118.

Triguero, A., Moreno-Mondéjar, L., and Davia, M. A. (2013). "Drivers of different types of eco-innovation in European SMEs," Ecological Economics 92, 25-33. DOI: 10.1016/j.ecolecon.2013.04.009

Úrad Vlády SR (2001). Národná Stratégia Trvalo Udržatel’ného Rozvoja [National Sustainable Development Strategy], Úrad Vlády Slovenskej Republiky, Bratislava, Slovakia.

Zhen, H. (2011). "Research on the evaluation of China's provincial eco-innovation capability," Energy Procedia 5, 647-653. DOI: 10.1016/j.egypro.2011.03.114

Article submitted: April 7, 2020; Peer review completed: May 16, 2020; Revised version received and accepted: May 19, 2020; Published: May 21, 2020.

DOI: $10.15376 /$ biores. 15.3.5355-5365 